Article

\title{
Chemical Composition of Essential Oil from Italian Populations of Artemisia alba Turra (Asteraceae)
}

\author{
Antonella Maggio ${ }^{1, *}$, Sergio Rosselli ${ }^{1}$, Maurizio Bruno ${ }^{1}$, Vivienne Spadaro ${ }^{2}$, \\ Francesco Maria Raimondo ${ }^{2}$ and Felice Senatore ${ }^{3}$
}

1 Department of Molecular and Biomolecular Science and Technology (STeMBio), Organic Chemistry Section, Palermo University, Viale delle Scienze, Palermo 90128, Italy

2 Department of Environmental Biology and Biodiversity, Palermo University, Via Archirafi 38, Palermo 90123, Italy

3 Department of Chemistry of Natural Products, University of Naples "Federico II", Via D. Montesano, Naples 49-80131, Italy

* Author to whom correspondence should be addressed; E-Mail: antonella.maggio@unipa.it; Tel.: +39-091-238-97542; Fax: +39-091-596825.

Received: 21 July 2012; in revised form: 10 August 2012 / Accepted: 13 August 2012 /

Published: 27 August 2012

\begin{abstract}
The use of essential oils as chemotaxonomic markers could be useful for the classification of Artemisia species and to caracterize biodiversity in the different populations. An analysis of the chemical composition of four essential oils from Italian populations of Artemisia alba Turra (collected in Sicily, Marche and Abruzzo) was investigated. In this paper an in depth study of the significant differences observed in the composition of these oils is reported.
\end{abstract}

Keywords: Artemisia alba; essential oil; biodiversity; $\alpha$-bisabolone oxide A; davanone D

\section{Introduction}

Artemisia L. is a large, important genus of the Asteraceae family. It comprises more than 500 species [1] although in the past this number has fluctuated depending on authors' opinions [2,3]. Artemisia is a cosmopolitan genus, mainly distributed in temperate areas of mid to high latitudes of the Northern Hemisphere, with only a few representatives in the Southern Hemisphere. Central Asia is its 
center of diversification, while the Mediterranean region and North West America are two secondary speciation areas [4,5]. Some species are also reported in Africa and Europe [3,6].

Due to the high number of species, Artemisia is a taxonomically complex genus because some species have different morphological forms and others closely resemble each other. For this reason a correct identification, based only on morphological details, is quite difficult. The genus has been divided in four subgenus: Abrotanum Bess., Absinthium (Miller) DC., Seriphidium Bess. and Dracunculus Bess [7] although more recently the subgenera Abrotanum, Absinthium, Seriphidium have been joined in the subgenus Artemisia [6].

Artemisia alba Turra is found in the southern part of Europe and is widespread in Italy with the exception of Sardinia [8], and due to its morphological variability has an uncertain botanical placement since some authors have included it in several different subgenus: Absinthium [9], Abrotanum [10] or Artemisia [6]. As confirmation of this complexity, the Sicilian population of this species, due to its peculiar morphological characters, was assigned, in the past, to a differently named intraspecific taxon: A. camphorata Vill. var. subcanescens Ten. [11], A. alba var. incanescens (Jord.) Fiori [9].

Previous chemical studies indicate that patterns of secondary metabolites present in plants of the genera Artemisia include triterpenes, steroids, hydrocarbons, polyacetylenes, flavonoids, coumarins, mono and sesquiterpenoids with a wide range of biological activities such as antimalarial, cytotoxic, antihepatotoxic, anti-bacterial, antifungal and antioxidant properties [12,13].

Concerning phytochemical investigations of $A$. alba, only four papers have been published on the non-volatile components; three papers have been published considering its synonyms $A$. lobelii All. [14-16], A. biasolettiana Vis., A. suavis Jord., A. incanescens Jord., A. camphorata Vill. listed in the European Flora database [17]. Santonin was isolated from the aerial parts [18], whereas the roots were shown to contain a sesquiterpene-coumarin ether [10]. Studies on the aerial parts of A. alba collected in Calabria showed the absence of sesquiterpenoids and the presence of several nerolidol derivatives [19]. This latter data are in agreement with recent studies [20] according to which the population occurring in Calabria is to be assigned to a diploid subspecies (A. alba subsp.chitachensis Maire). Artalbic acid, a sesquiterpene with an unusual skeleton, was isolated from the aerial parts of $A$. alba collected in Sicily [21], corresponding to a tetraploid population of this species [22].

The use of essential oils as chemotaxonomic markers could be useful for the classification of Artemisia species and to characterize the biodiversity of the different populations. The GC-MS analysis of essential oils of 14 Artemisia species collected in the North West Italian Alps has allowed us to draw some interesting considerations on the classification of the genus Artemisia. In particular, A. alba is characterized by a high content of camphor like A. vallesiaca, A. glacias and A. vulgaris collected in the same region [23]. Camphor and isopinocamphone were particularly high in $A$. alba. The same chemical components were found in some Belgian populations of $A$. alba [24]. The content of monoterpenic aldehydes is high too and cuminaldehyde is the second most important component in the oil [23]. An interesting paper compared the essential oil compositions of two populations of $A$. alba wild growing on calcareous and serpentine substrates and pointed out the fact that the type of soil could have an important influence on the biosynthesis of $A$. alba volatiles, especially in the case of populations grown on serpentine rock, characterized by deficiency of water and indispensable mineral elements. The camphor content is high in $A$. alba from a calcareus habitat, whereas germacrene $\mathrm{D}$ is the major component in serpentinophyte $A$. alba [25]. 


\section{Results and Discussion}

Hydrodistillation of the aerial parts of $A$. alba Turra collected in Madonie (A), Marche (B), Majella (C) and Mt. Velino (D) yielded 1.5\%, 0.4\%, 0.16\% and 0.03\% (w/w) of essential oils, respectively, all characterized by a pale yellow colour. In Table 1 the compounds identified are listed according to their retention indices on a HP-5MS column, and are classified in seven classes on the basis of their chemical structures. The composition of the oils is different, both qualitatively and quantitatively. The oil obtained from Artemisia alba from Madonie (A) is characterized by a high concentration of sesquiterpenes that represents more than $60 \%$ of the composition of the oil, while in the oils of other populations the presence of monoterpenes and sesquiterpenes is roughly equivalent.

Table 1. Composition (\%) of essential oils from aerial parts of Artemisia alba Turra collected in Madonie (A), Marche (B), Majella (C) and Mt. Velino (D).

\begin{tabular}{|c|c|c|c|c|c|c|c|}
\hline $\mathbf{K}_{\mathbf{i}}{ }^{\mathbf{a}}$ & $\mathbf{K}_{\mathbf{i}}{ }^{\mathbf{b}}$ & Component & Ident. & $\mathbf{A}$ & B & $\mathbf{C}$ & D \\
\hline \multicolumn{8}{|c|}{ Monoterpene Hydrocarbons } \\
\hline 909 & 1032 & Santolina triene & 1,2 & 7.3 & 1.2 & & \\
\hline 931 & 1023 & $\alpha$-Thujene & 1,2 & & 0.1 & & \\
\hline 938 & 1032 & $\alpha$-Pinene & $1,2,3$ & & 1.7 & 0.3 & \\
\hline 953 & 1076 & Camphene & 1,2 & 1.2 & & 0.1 & \\
\hline 973 & 1132 & Sabinene & 1,2 & 0.6 & & & \\
\hline 980 & 1118 & $\beta$-Pinene & $1,2,3$ & 0.5 & 2.7 & 0.3 & \\
\hline 1025 & 1278 & $p$-Cymene & $1,2,3$ & 0.5 & & 0.2 & \\
\hline 1030 & 1203 & Limonene & $1,2,3$ & 1.0 & & & \\
\hline 1057 & 1256 & $\gamma$-Terpinene & $1,2,3$ & 0.2 & & & \\
\hline \multirow[t]{2}{*}{1114} & 1408 & 1,3,8-p-Menthatriene & 1,2 & & 0.1 & & \\
\hline & & Total & & 11.3 & 5.8 & 0.9 & - \\
\hline \multicolumn{8}{|c|}{ Oxygenated Monoterpenes } \\
\hline 1024 & 1402 & Santolina alcohol & 1,2 & 2.6 & 0.2 & & \\
\hline 1034 & 1213 & 1,8-Cineole & $1,2,3$ & 1.6 & 0.7 & 0.1 & \\
\hline 1063 & 1555 & cis-Sabinene hydrate & 1,2 & & & 0.2 & 0.2 \\
\hline 1063 & 1358 & Artemisia ketone & 1,2 & & 4.6 & & \\
\hline 1085 & 1512 & Artemisia alcohol & 1,2 & & 6.0 & & \\
\hline 1093 & 1474 & trans-Sabinene hydrate & 1,2 & & 1.1 & 0.3 & $\mathrm{t}$ \\
\hline 1098 & 1553 & Linalool & $1,2,3$ & & 0.6 & & 0.1 \\
\hline 1108 & 1616 & Hotrienol & & & & & 3.3 \\
\hline 1115 & 1451 & $\beta$-Thujone & 1,2 & & & 0.7 & \\
\hline 1117 & 1571 & trans-p-Menth-2-en-1-ol & 1,2 & & & 0.3 & \\
\hline 1125 & 1540 & Chrysanthenone & 1,2 & 1.1 & 3.1 & & \\
\hline 1128 & 1487 & $\alpha$-Campholenal & 1,2 & & & 0.2 & \\
\hline 1138 & 1664 & trans-Pinocarveol & 1,2 & & 0.1 & & \\
\hline 1145 & 1532 & Camphor & $1,2,3$ & 1.6 & 3.4 & 0.7 & \\
\hline 1146 & & Neolyratol & 1,2 & & & & 0.3 \\
\hline
\end{tabular}


Table 1. Cont.

\begin{tabular}{|c|c|c|c|c|c|c|c|}
\hline$K_{i}^{a}$ & $\mathbf{K}_{\mathrm{i}}{ }^{\mathbf{b}}$ & Component & Ident. & $\mathbf{A}$ & $\mathbf{B}$ & $\mathbf{C}$ & D \\
\hline \multicolumn{8}{|c|}{ Oxygenated Monoterpenes } \\
\hline 1149 & 1685 & trans-Verbenol & 1,2 & & 0.2 & 1.8 & \\
\hline 1164 & 1684 & trans-Chrysanthenol & 1,2 & & & & 0.4 \\
\hline 1165 & 1587 & Pinocarvone & 1,2 & & & 1.6 & \\
\hline 1167 & 1719 & Borneol & $1,2,3$ & 2.1 & 9.3 & 0.7 & \\
\hline 1174 & 1565 & cis-Pinocamphone & 1,2 & & & 14.9 & 1.1 \\
\hline 1176 & 1611 & Terpinen-4-ol & $1,2,3$ & 1.5 & 0.6 & & 1.2 \\
\hline 1183 & 1757 & cis-Piperitol & 1,2 & & & & 0.2 \\
\hline 1185 & 1856 & $p$-Cymen-8-ol & 1,2 & & & 0.3 & 0.1 \\
\hline 1189 & 1706 & $\alpha$-Terpineol & $1,2,3$ & 0.5 & 1.2 & & 0.7 \\
\hline 1193 & 1648 & Myrtenal & 1,2 & & 0.7 & 0.2 & \\
\hline 1197 & 1805 & Myrtenol & 1,2 & 0.6 & 1.2 & 1.4 & 0.5 \\
\hline 1201 & 1618 & Safranal & 1,2 & & 0.1 & & \\
\hline 1217 & 1845 & trans-Carveol & 1,2 & 0.5 & 1.6 & 0.5 & \\
\hline 1226 & 1878 & cis-Carveol & 1,2 & 0.7 & 0.3 & 0.4 & \\
\hline 1238 & 1694 & Neral & 1,2 & & & & 0.4 \\
\hline 1241 & 1752 & Carvone & 1,2 & & 0.2 & 0.4 & \\
\hline 1268 & 1741 & Geranial & 1,2 & & & & 0.3 \\
\hline 1293 & 2198 & Thymol & $1,2,3$ & & & 0.4 & \\
\hline 1299 & 2239 & Carvacrol & $1,2,3$ & & 0.1 & & \\
\hline \multirow[t]{2}{*}{1343} & 1748 & Piperitone & 1,2 & & 2.2 & 12.6 & 32.8 \\
\hline & & Total & & 12.8 & 37.5 & $\mathbf{3 7 . 7}$ & 41.6 \\
\hline \multicolumn{8}{|c|}{ Sesquiterpene Hydrocarbons } \\
\hline 1352 & 1466 & $\alpha$-Cubebene & 1,2 & & 0.2 & & \\
\hline 1377 & 1497 & $\alpha$-Copaene & 1,2 & & & 0.3 & \\
\hline 1385 & 1535 & $\beta$-Bourbonene & 1,2 & & 0.3 & 0.1 & \\
\hline 1387 & 1594 & $\beta$-Elemene & 1,2 & & 1.0 & 0.4 & 0.4 \\
\hline 1415 & 1612 & $\beta$-Caryophyllene & $1,2,3$ & & 0.9 & 0.3 & 0.6 \\
\hline 1437 & 1530 & $\alpha$-Guaiene & 1,2 & & & 0.2 & \\
\hline 1453 & 1673 & (E)- $\beta$-Farnesene & 1,2 & 1.2 & & & \\
\hline 1455 & 1689 & $\alpha$-Humulene & 1,2 & & 1.3 & 0.2 & $\mathrm{t}$ \\
\hline 1463 & 1667 & allo-Aromadendrene & 1,2 & 0.9 & & & 0.5 \\
\hline 1474 & 1682 & $\gamma$-Gurjunene & 1,2 & 6.4 & 1.0 & & \\
\hline 1477 & 1726 & Germacrene D & 1,2 & & 2.1 & 4.9 & 10.2 \\
\hline 1478 & 1704 & $\gamma$-Muurolene & 1,2 & & 0.6 & & \\
\hline 1482 & 1741 & $\beta$-Eudesmene $(\beta$-Selinene $)$ & 1,2 & & & 0.3 & \\
\hline 1486 & 1733 & $\alpha$-Selinene & 1,2 & & 7.6 & 0.5 & \\
\hline 1487 & 1679 & $\alpha$-Amorphene & 1,2 & & & & 0.4 \\
\hline 1489 & 1729 & $(Z, E)$ - $\alpha$-Farnesene & 1,2 & 2.7 & & & \\
\hline 1490 & 1694 & $\beta$-Guaiene & 1,2 & 0.2 & 0.3 & & \\
\hline 1491 & 1756 & Bicyclogermacrene & 1,2 & & 2.5 & & \\
\hline 1506 & 1760 & $(E, E)-\alpha$-Farnesene & 1,2 & 1.5 & & & \\
\hline 1509 & 1746 & $\operatorname{cis}-(Z)-\alpha$-Bisabolene & 1,2 & 0.8 & 2.7 & & \\
\hline 1510 & 1743 & $\beta$-Bisabolene & 1,2 & & & & 0.6 \\
\hline
\end{tabular}


Table 1. Cont.

\begin{tabular}{|c|c|c|c|c|c|c|c|}
\hline $\mathbf{K}_{\mathbf{i}}{ }^{\mathbf{2}}$ & $\mathbf{K}_{\mathbf{i}}{ }^{\mathbf{b}}$ & Component & Ident. & $\mathbf{A}$ & B & $\mathbf{C}$ & $\mathbf{D}$ \\
\hline \multicolumn{8}{|c|}{ Sesquiterpene Hydrocarbons } \\
\hline 1515 & 1776 & $\gamma$-Cadinene & 1,2 & 0.5 & & & \\
\hline 1520 & 1839 & 1-S-cis-Calamenene & 1,2 & & 0.1 & & \\
\hline 1526 & 1773 & $\delta$-Cadinene & 1,2 & 1.5 & 0.4 & 0.3 & 0.4 \\
\hline 1554 & 1856 & Germacrene B & 1,2 & & & 0.3 & \\
\hline & & Total & & 15.7 & 21.0 & 7.8 & 13.1 \\
\hline \multicolumn{8}{|c|}{ Oxygenated Sesquiterpenes } \\
\hline 1234 & 1641 & nor-Davanone & 1,2 & 0.1 & & & \\
\hline 1457 & 1712 & Cabreuva oxide B & 1,2 & & & & 0.9 \\
\hline 1476 & & Davana ether & 1,2 & 0.3 & & & \\
\hline 1534 & 1991 & Artedouglasia oxide A & 1,2 & 0.9 & & & \\
\hline 1559 & 1967 & Davanone B & 1,2 & 0.8 & & & \\
\hline 1563 & 2065 & Artedouglasia oxide D & 1,2 & 0.6 & & & \\
\hline 1564 & 2050 & (E)-Nerolidol & 1,2 & & & 0.6 & 6.4 \\
\hline 1564 & 2056 & Ledol & 1,2 & & 0.2 & & \\
\hline 1578 & 2150 & Spathulenol & $1,2,3$ & 1.6 & 4.2 & 0.4 & 2.1 \\
\hline 1580 & 2008 & Caryophyllene oxide & $1,2,3$ & & 1.8 & 1.1 & 2.0 \\
\hline 1587 & 2108 & Dihydronerolidol & 1,2 & & & & 2.9 \\
\hline 1588 & 2025 & Davanone D & 1,2 & 10.5 & & & \\
\hline 1591 & 2104 & Viridiflorol & 1,2 & & 0.4 & & \\
\hline 1598 & 2107 & Guaiol & 1,2 & & 2.8 & & \\
\hline 1638 & 2223 & Isospathulenol & 1,2 & 0.7 & 0.1 & & \\
\hline 1640 & 2185 & T-Cadinol & 1,2 & & & & 2.8 \\
\hline 1641 & 2209 & T-Muurolol & 1,2 & & & & 0.9 \\
\hline 1648 & 2399 & Aromadendrene oxide & 1,2 & & & & 1.0 \\
\hline 1653 & 2252 & $\alpha$-Eudesmol & 1,2 & & & 42.2 & \\
\hline 1655 & & $\mathrm{a} \mathrm{C}_{15} \mathrm{H}_{22} \mathrm{O}$ & 1,2 & & 1.1 & & \\
\hline 1657 & 2217 & $\alpha$-Bisabolone oxide A & 1,2 & 16.4 & & & \\
\hline 1658 & 2156 & $\alpha$-Bisabolol oxide B & 1,2 & 2.2 & & & \\
\hline 1675 & 2213 & (Z)- $\alpha$-Bisabolene epoxide & 1,2 & 0.5 & & & \\
\hline 1682 & 2246 & Bisabolone oxide & 1,2 & 9.0 & & & \\
\hline 1682 & 2232 & $\alpha$-Bisabolol & 1,2 & 0.8 & 1.7 & & 4.5 \\
\hline 1687 & 1896 & allo-Aromadendrene oxide & 1,2 & & 0.4 & 0.2 & 0.8 \\
\hline 1689 & 2359 & 8-Cedren-13-ol & 1,2 & & 10.3 & & \\
\hline 1692 & 2342 & $(2 Z, 6 E)$-Farnesol & 1,2 & & & & 1.9 \\
\hline 1692 & 2245 & epi- $\alpha$-Bisabolol & 1,2 & 0.8 & & & 4.7 \\
\hline 1738 & 2162 & $\alpha$-Bisabolol oxide A & 1,2 & 1.4 & & & \\
\hline \multirow[t]{2}{*}{1765} & 2518 & $c i s$-Lanceol & 1,2 & 0.4 & 0.2 & & \\
\hline & & Total & & 47.0 & 23.2 & 44.5 & 30.9 \\
\hline \multicolumn{8}{|c|}{ Others } \\
\hline 977 & 1452 & 1-Octen-3-ol & 1,2 & & & 0.2 & \\
\hline 1123 & 1570 & Isophorone & 1,2 & & $\mathrm{t}$ & & \\
\hline 1206 & 1510 & Decanal & 1,2 & & 0.2 & & \\
\hline 1397 & 1959 & cis-Jasmone & 1,2 & 0.1 & & & \\
\hline
\end{tabular}


Table 1. Cont.

\begin{tabular}{|c|c|c|c|c|c|c|c|}
\hline $\mathbf{K}_{\mathrm{i}}^{\mathrm{a}}$ & $\mathbf{K}_{\mathrm{i}}^{\mathbf{b}}$ & Component & Ident. & $\mathbf{A}$ & B & $\mathbf{C}$ & D \\
\hline \multicolumn{8}{|c|}{ Others } \\
\hline \multirow[t]{2}{*}{1405} & 2031 & Methyleugenol & 1,2 & 0.6 & 0.3 & & \\
\hline & & Total & & 0.7 & 0.5 & 0.2 & - \\
\hline \multicolumn{8}{|c|}{ Esters } \\
\hline 1235 & 1583 & trans-Chrysanthenyl acetate & 1,2 & 1.4 & 2.1 & & 1.6 \\
\hline 1241 & & Linalyl formate & 1,2 & & 0.1 & & \\
\hline 1264 & 1561 & cis-Chrysanthenyl acetate & 1,2 & 0.6 & $\mathrm{t}$ & & 1.5 \\
\hline 1286 & 1567 & Bornyl acetate & $1,2,3$ & 0.5 & & 0.2 & \\
\hline 1325 & 1678 & Myrtenyl acetate & 1,2 & & & 0.3 & \\
\hline 1362 & 1729 & Neryl acetate & 1,2 & & & & 0.5 \\
\hline \multirow[t]{2}{*}{1818} & 1716 & $(2 Z, 6 E)$-Farnesyl acetate & 1,2 & $\mathrm{t}$ & & & \\
\hline & & Total & & 2.5 & 2.2 & 0.5 & 3.6 \\
\hline \multicolumn{8}{|c|}{ Oxygenated diterpenes } \\
\hline \multirow[t]{3}{*}{2135} & 2625 & (E)-Phytol & 1,2 & & & & 1.1 \\
\hline & & Total compounds & & 47 & 57 & 41 & 38 \\
\hline & & TOTAL & & 90.0 & 90.2 & 91.6 & 90.3 \\
\hline
\end{tabular}

All oil extracts from the populations of Marche, Majella and Monte Velino have a content of monoterpenes $(43.3 \%, 38.6 \%$ and $41.6 \%$, respectively), which is about twice as high compared with the same class of compounds identified in the oil from Madonie (24.1\%).

Among the monoterpenic hydrocarbons in the oil from Madonie, santolinatriene (7.3\%), an irregular monoterpene, predominates and it is also present in low concentrations in $\mathbf{B}$, but absent in $\mathbf{C}$ and D. On the other hand in the oil from Marche irregular oxygenated monoterpenes are found in higher concentrations. In fact, santolina alcohol, artemisia alcohol, artemisia ketone and chrysanthenone represent about one third (13.9\%) of the fraction while in the oil from Madonie santolina alcohol, despite being the most abundant oxygenated monoterpene, accounts for only $2.6 \%$, the remaining $(10.2 \%)$ of this fraction being constituted by regular oxygenated monoterpenes. The most abundant oxygenated monoterpenes of oil from Marche are borneol (9.3\%), artemisia alcohol (6.0\%) and artemisia ketone (4.6\%); the last two being absent in A, C and D. In the oils from Abruzzo (Majella, C and Monte Velino, D) monoterpenic ketones (cis-pinocamphone, piperitone) are prevalent instead and they account for more than half of the content of monoterpenes.

Concerning the content of oxygenated sequiterpenes, although the total percentages are similar in the four populations, the proportion of the various types of compounds changes drastically. In fact in $\mathbf{A}$ ketones (11.5\%) and oxides (31.4\%) are prevalent with davanone D (10.5\%) and $\alpha$-bisabolone oxide A (16.4\%) as main compounds, while alcohols represent only $4.3 \%$. On the other hand in $\mathbf{B}, \mathbf{C}$ and $\mathbf{D}$, the content of sesquiterpene alcohols is very high $(19.9 \%, 42.2 \%$ and $26.2 \%$, respectively). The main compounds among the sesquiterpene alcohols are: 8-cedren-13-ol (10.3\%) in the oil from Marche, $\alpha$-eudesmol (42.2\%) in the oil from Majella and epi-a-bisabolol (4.7\%), $\alpha$-bisabolol (4.5\%) and $(E)$-nerolidol (6.4\%) in the oil from Monte Velino. 
According to the literature [17] $\alpha$-thujone and camphor are two markers allowing a distinction of Artemisia in two groups. Our four oils are characterized by the absence of $\alpha$-thujone, whereas camphor and its biogenetic precursor, borneol are present in $\mathbf{A}, \mathbf{B}$ and $\mathbf{C}$.

\section{Experimental}

\subsection{Plant Material}

The aerial parts of the four populations of Artemisia alba Turra, were collected from blooming plants in Sicily, pastures on carbonate soils at Pizzo Carbonara (Madonie), in spring of 2011 (A); Marche, pastures on carbonate soils between Fabriano (Ancona) and Matelica (Macerata), in spring of 2011, Abruzzo: pastures on carbonate soils at Mt Majella (C) and Mt Velino (D), in summer of 2011 (Figure 1). Samples of the studied material, identified by the authors F. M. Raimondo and V. Spadaro, are kept in the Herbarium Mediterraneum of the Palermo University [Raimondo \& Spadaro (PAL)].

Figure 1. Map of the samples' origins: Madonie (A), Marche (B), Majella (C) and Mt. Velino (D) are indicated.

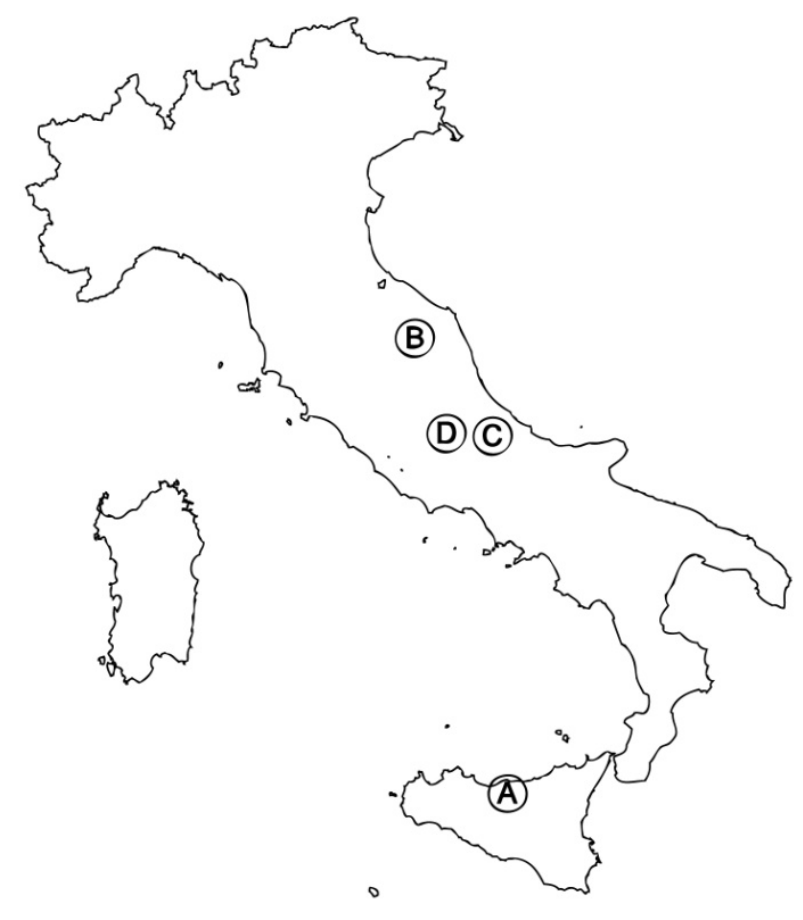

\subsection{Isolation of the Essential Oil}

The air-dried samples were ground in a Waring blender and then subjected to hydrodistillation for $3 \mathrm{~h}$ using $n$-hexane as solvent, according to the standard procedure of the European Pharmacopoeia [26]. The extracts were dried over anhydrous sodium sulphate and then stored in sealed vials, at $-20{ }^{\circ} \mathrm{C}$, ready for the GC and GC-MS analyses. The samples yielded $1.5 \%(\mathbf{A}), 0.40 \%(\mathbf{B}), 0.16 \%(\mathbf{C})$ and $0.03 \%(D)(\mathrm{w} / \mathrm{w})$ of pleasant smelling yellow oils. 


\subsection{Gas Chromatography-Mass Spectrometry}

Analytical gas chromatography was carried out on a Perkin-Elmer Sigma 115 gas chromatograph (Napoli, Italy) equipped with a HP-5MS capillary column $(30 \mathrm{~m} \times 0.25 \mathrm{~mm}, 0.25 \mu \mathrm{m}$ film thickness), a split-splitless injector heated at $250{ }^{\circ} \mathrm{C}$ and a flame ionization detector (FID) at $280{ }^{\circ} \mathrm{C}$. Column temperature was initially kept at $40{ }^{\circ} \mathrm{C}$ for $5 \mathrm{~min}$, then gradually increased to $250{ }^{\circ} \mathrm{C}$ at $2{ }^{\circ} \mathrm{C} / \mathrm{min}$, held for $15 \mathrm{~min}$ and finally raised to $270{ }^{\circ} \mathrm{C}$ at $10{ }^{\circ} \mathrm{C} / \mathrm{min}$. The injection volume was $1.0 \mu \mathrm{L}$ (split ratio 1:20). A fused silica HP Innowax polyethylene glycol capillary column $(50 \mathrm{~m} \times 0.20 \mathrm{~mm}, 0.25 \mu \mathrm{m}$ film thickness) was also used for analysis. In both cases helium was the carrier gas (1 $\mathrm{mL} / \mathrm{min})$. GC-MS analysis was performed on an Agilent 6850 Ser. II apparatus (Napoli, Italy), fitted with a fused silica DB-5 capillary column ( $30 \mathrm{~m} \times 0.25 \mathrm{~mm}, 0.33 \mu \mathrm{m}$ film thickness), coupled to an Agilent Mass Selective Detector MSD 5973; ionization voltage $70 \mathrm{eV}$; electron multiplier energy $2000 \mathrm{~V}$; source temperature $250{ }^{\circ} \mathrm{C}$. Mass spectra were scanned in the range 35-450 amu, scan time $5 \mathrm{scans} / \mathrm{s}$. Gas chromatographic conditions were the same as those for GC; transfer line temperature, $295^{\circ} \mathrm{C}$.

\subsection{Identification of Components}

Most of the constituents were identified by GC by comparison of their retention indices $\left(\mathrm{K}_{\mathrm{i}}\right)$ with either those in the literature $[27,28]$ or with those of authentic compounds available in our laboratories. Retention indices were determined in relation to a homologous series of $n$-alkanes $\left(\mathrm{C}_{8}-\mathrm{C}_{28}\right)$ under the same conditions. Whenever possible, co-injection with authentic substances was also performed. Component-related concentrations were calculated based on GC peak areas without using correction factors. Further identification of oil components was achieved by comparing their mass spectra on both columns, either with those stored in NIST 02 and Wiley 275 libraries or with mass spectra from the literature $[28,29]$ and our personal library.

\section{Conclusions}

The differences in composition between the four oils makes it possible to hypothesize that the Italian populations of Artemisia alba Turra growing on the Madonie (Sicily), in the Marche region, on the Majella and Monte Velino (Abruzzo) - in part related to different cytotypes [19] — surely express from climatic as well as genetic differences. Furthemore, the differences of the oil of the population of the Artemisia alba Turra from Madonie - the most southerly of the species - let us consider that this belongs to a different chemotype from the other ones.

\section{Acknowledgments}

This research was supported by Italian Government fund MIUR PRIN 2009 "Composti naturali da piante mediterranee e loro derivati sintetici con attivita antitumorale". The GC-MS spectra were performed at the "C.S.I.A.S." of the University "Federico II" of Napoli. The assistance of the staff is gratefully appreciated. 


\section{References}

1. Oberprieler, C.; Himmelreich, S.; Vogt, R. A new subtribal classification of the tribe Anthemideae (Compositae). Willdenowia 2007, 37, 89-114.

2. Bremer, K.; Humphries, C.J. Generic monograph of the Asteraceae-Anthemideae. Bull. Nat. His. Mus. 1993, 23, 71-177.

3. Ling, Y.R. The genera Artemisia L. and Seriphidium (Bess.) Poljak. in the world. Compositae Newsl. 1994, 25, 39-45.

4. McArthur, E.D.; Plummer, A.P. Biogeography and management of native Western shrubs: A case study, section Tridentatae of Artemisia. Great Basin Nat. Mem. 1978, 2, 229-243.

5. Valles, J.; Torrell, M.; Garnatje, T.; Garcia-Jacas, N.; Vilatersana, R.; Susanna, A. The genus Artemisia and its allies: Phylogeny of the subtribe Artemisiinae (Asteraceae, Anthemideae) based on nucleotide sequences of nuclear ribosomal DNA internal transcribed spacers (ITS). Plant Biol. 2003, 5, 274-284.

6. Tutin, T.G.; Persson, K.; Guttermann, W. Artemisia L. In Flora Europaea; Tutin, T.G., Heywood, V.H., Burges, N.A., Valentine, D.H., Walters, S.M., Webb, D.A., Eds.; Cambridge University Press: Cambridge, UK, 1976; Volume 4, pp. 178-186.

7. Besser, W.S. Synopsis Absinthiorum. Bull. Soc. Imp. Natl. Mosc. 1829, 1, 219-265.

8. Pignatti, S. Flora d'Italia; Edagricole: Bologna, Italy, 1982; Volume 3, p. 107.

9. Fiori, A. Nuova Flora Analitica d'Italia; Ricci: Firenze, Italy, 1927; Volume 2, pp. 631-639.

10. Greger, H.; Haslinger, E.; Hofer, O. Naturally occurring sesquiterpene-coumarin ethers. Part 2. Albartin, a new sesquiterpene-coumarin ether from Artemisia alba. Monatsh. Chem. 1982, 113, 375-379.

11. Lojacono Pojero, M. Flora sicula, o Descrizione Delle Piante Vascolari Spontanee o Indigenate in Sicilia; Tip. Boccone Del Povero: Palermo, Italy, 1903; Volume 2, p. 72.

12. Tan, R.X.; Zheng, W.F.; Tang, H.Q. Biologically active substances from the genus Artemisia. Planta Med. 1998, 64, 295-302.

13. Bora, K.S.; Sharma, A. Evaluation of antioxidant and free-radical scavenging potential of Artemisia absinthium. Pharm. Biol. 2011, 49, 101-109.

14. Gorunovic, M.S.; Bogavac, P.M.; Chalchat, J.C.; Garry, R.P. Analysis of the essential oil of Artemisia lobelii All. Pharmazie 1992, 47, 803-804.

15. Stojanovic, G.; Palic, R.; Mitrovic, J.; Djokovic, D. Chemical composition and antimicrobial activity of the essential oil of Artemisia lobelii All. J. Essent. Oil Res. 2000, 12, 621-624.

16. Blagojevic, P.D.; Jovanovic, M.M.; Palic, R.M.; Stojanovic, G.S. Changes in the volatile profile of the Artemisia lobelii All. during prolonged plant material storage. J. Essent. Oil Res. 2009, 21, 497-500.

17. Flora Europaea Search Results Home Page. Available oninle: http://rbg-web2.rbge.org.uk/ cgi-bin/nph-readbtree.pl/feout?FAMILY_XREF=\&GENUS_XREF=Artemisia\&SPECIES_XREF= $\& T A X O N \_N A M E \_X R E F=\& R A N K=($ accessed on 31 July 2012).

18. Janot, M.M.; Gautier, J. Some Artemisia species from Persia and their santonine content. Bull. Sci. Pharmacol. 1935, 42, 404-408. 
19. Appendino, G.; Gariboldi, P.; Menichini, F. Oxygenated nerolidol derivatives from Artemisia alba. Phytochemistry 1985, 24, 1729-1733.

20. Peruzzi, L.; Gargano, D.; Cesca, G. Karyological observations on Artemisia alba Turra (Asteraceae). Caryologia 2005, 58, 78-82.

21. Maggio, A.; Rosselli, S.; Brancazio, C.L.; Safder, M.; Spadaro, V.; Bruno, M. Artalbic acid, a sesquiterpene with an unusual skeleton from Artemisia alba (Asteraceae) from Sicily. Tetrahedron Lett. 2011, 52, 4543-4545.

22. Raimondo, F.M.; Rossitto, M.; Ottonello, D. Numeri cromosomici per la flora Italiana: 967-976. Inform. Bot. Ital. 1984, 15, 58-65.

23. Mucciarelli, M.; Caramiello, R.; Maffei, M. Essential oils from some Artemisia species growing spontaneously in north-west Italy. Flav. Frag. J. 1995, 10, 25-32.

24. Ronse, A.C.; De Pooter, H.L. Essential oil production by Belgian Artemisia alba (Turra) before and after micropropagation. J. Essent. Oil Res. 1990, 2, 237.

25. Radulovic, N.; Blagojevic, P. Volatile profiles of Artemisia alba from contrasting serpentine and calcareous habitats. Nat. Prod. Commun. 2010, 5, 1117-1122.

26. Council of Europe. European Pharmacopoeia, 5th ed.; Council of Europe: Strasbourg Cedex, France, 2004; Volume I, pp. 217-218.

27. Davies, N.W. Gas Chromatographic retention indexes of monoterpenes and sesquiterpenes on methyl silicone and Carbowax 20M phases. J. Chromatogr. A 1990, 503, 1-24.

28. Jennings, W.; Shibamoto, T. Qualitative Analysis of Flavour and Fragrance Volatiles by Glass Capillary Gas Chromatography; Academic Press: New York, NY, USA, 1980.

29. Adams, R.P. Identification of Essential Oil Components by Gas Chromatography/Mass Spectrometry, 4th ed.; Allured Publishing Co.: Carol Stream, IL, USA, 2007.

Sample Availability: Samples of the oils are available from the authors.

(C) 2012 by the authors; licensee MDPI, Basel, Switzerland. This article is an open access article distributed under the terms and conditions of the Creative Commons Attribution license (http://creativecommons.org/licenses/by/3.0/). 